\title{
Holocene ages and inland source of wood blocks that emerged onto the seafloor during the 2007 Chuetsu-oki, central Japan, earthquake
}

\author{
Heitaro Kaneda ${ }^{1}$, Makoto Nakata ${ }^{2}$, Yoshihiro Hosoo $^{3}$, Yuichi Sugiyama ${ }^{1}$, and Yukinobu Okamura ${ }^{1}$ \\ ${ }^{1}$ Geological Survey of Japan, AIST, Tsukuba 305-8567, Japan \\ ${ }^{2}$ Graduate School of Science and Technology, Niigata University, Niigata 950-2181, Japan \\ ${ }^{3}$ International Young Researchers Empowerment Center, Shinshu University, Minami-minowa 399-4598, Japan
}

(Received November 29, 2007; Revised May 19, 2008; Accepted May 29, 2008; Online published November 18, 2008)

\begin{abstract}
At least 300 tons of subrounded to well-rounded wood blocks emerged onto the seafloor at a water depth of 70-100 m during the $2007 M_{\mathrm{w}} 6.6$ Chuetsu-oki, central Japan, earthquake. Radiocarbon dating and taxonomic identification of eight of those wood blocks suggest that they were transported from inland during the middle to late Holocene, buried by subsequent sedimentation, and brought up onto the seafloor in 2007, most likely by submarine liquefaction induced by strong shaking. In particular, all eight blocks gave ages older than $2500 \mathrm{cal} \mathrm{yr} \mathrm{BP}$, implying the possibility that the 2007 earthquake was the first earthquake during the last two millennia to have caused shaking strong enough to induce submarine liquefaction in the 2007 meizoseismal area. However, we cannot rule out the possibility of multiple large earthquakes after approximately $2 \mathrm{ka}$, if the buried wood sources cannot be emptied by a single earthquake. Further studies are required to examine paleoseismic implications of the emergence of these wood blocks in 2007.
\end{abstract}

Key words: 2007 Chuetsu-oki earthquake, wood block, seafloor, liquefaction, radiocarbon dating, paleoseismology.

\section{Introduction}

While exploratory on-fault trench excavation serves as an excellent paleoseismic tool for examining active faults on land, paleoseismic studies of submarine faults are not as straightforward, largely because of the inaccessibility of such faults. Instead, off-fault terrestrial geological features, such as tsunami deposits or emerged/submerged coastlines, are used to indirectly constrain the timing and size of prehistoric submarine earthquakes (e.g., Nanayama et al., 2003; Atwater et al., 2005). We address here another intriguing off-fault earthquake-induced feature, namely, the extensive emergence of wood blocks onto the seafloor during the 2007 $M_{\mathrm{w}} 6.6$ Chuetsu-oki, central Japan, earthquake. Although the emergence of manhole structures and underground water tanks is commonly reported following large earthquakes (e.g., Koseki et al., 1997; Geological Survey of Japan/AIST, 2004), few examples of coseismic emergence are known at the sea bottom. In one rare example, Tone (1965) reported the emergence of wood onto the seafloor at water depths of 70-80 $\mathrm{m}$ in response to the 1964 M 7.5 Niigata earthquake, the epicenter of which is located approximately $80 \mathrm{~km}$ northeast of the 2007 epicenter.

In this study, we used radiocarbon dating and taxonomic identification of eight of the 2007 wood blocks to examine provenance, emergence mechanism, and paleoseismic implications of the wood blocks.

Copyright (c) The Society of Geomagnetism and Earth, Planetary and Space Sciences (SGEPSS); The Seismological Society of Japan; The Volcanological Society of Japan; The Geodetic Society of Japan; The Japanese Society for Planetary Sciences; TERRAPUB.
2. The 2007 Chuetsu-oki Earthquake and the Emerged Submarine Wood Blocks

The $M_{\mathrm{w}} 6.6$ Chuetsu-oki earthquake occurred on 16 July 2007 , in the southernmost part of a NNE-trending fold-andthrust belt along the eastern margin of the Japan Sea (Fig. 1, inset). The hypocenter, determined by the Japan Meteorological Agency, is located approximately $6 \mathrm{~km}$ off the northwestern coast of central Honshu Island near Kashiwazaki, at a depth of $17 \mathrm{~km}$ (Fig. 1). The centroid moment tensor solution indicates a predominantly thrust-type slip on a northeast-striking source fault that dips either northwest or southeast. Although the direction of dip of the causative fault is still open to discussion, the aftershock distribution shows that the main rupture area extends along the coast for a distance of approximately $25 \mathrm{~km}$, from off Izumozaki to off the coast southwest of Kashiwazaki.

After the earthquake, resumed net fishing revealed that numerous wood blocks had emerged onto the seafloor off Cape Kannon during the earthquake. Because the wood blocks were getting caught in fishermen's nets, local fishery cooperatives collaboratively removed a total of approximately 300 tons of the wood blocks from the seafloor as of October 2007. The wood blocks vary in shape and size, but are mostly subrounded to well-rounded pieces with long axes that vary from a few tens to more than a hundred centimeters (Fig. 2(a); Nakata et al., 2008). On the basis of urgent surveys conducted by the Niigata Prefectural Fisheries and Marine Research Institute within 3 weeks after the earthquake, along with the results of the cooperatives' wood-removal operations, the wood blocks were found to be concentrated exclusively within a very narrow zone, $2-$ 


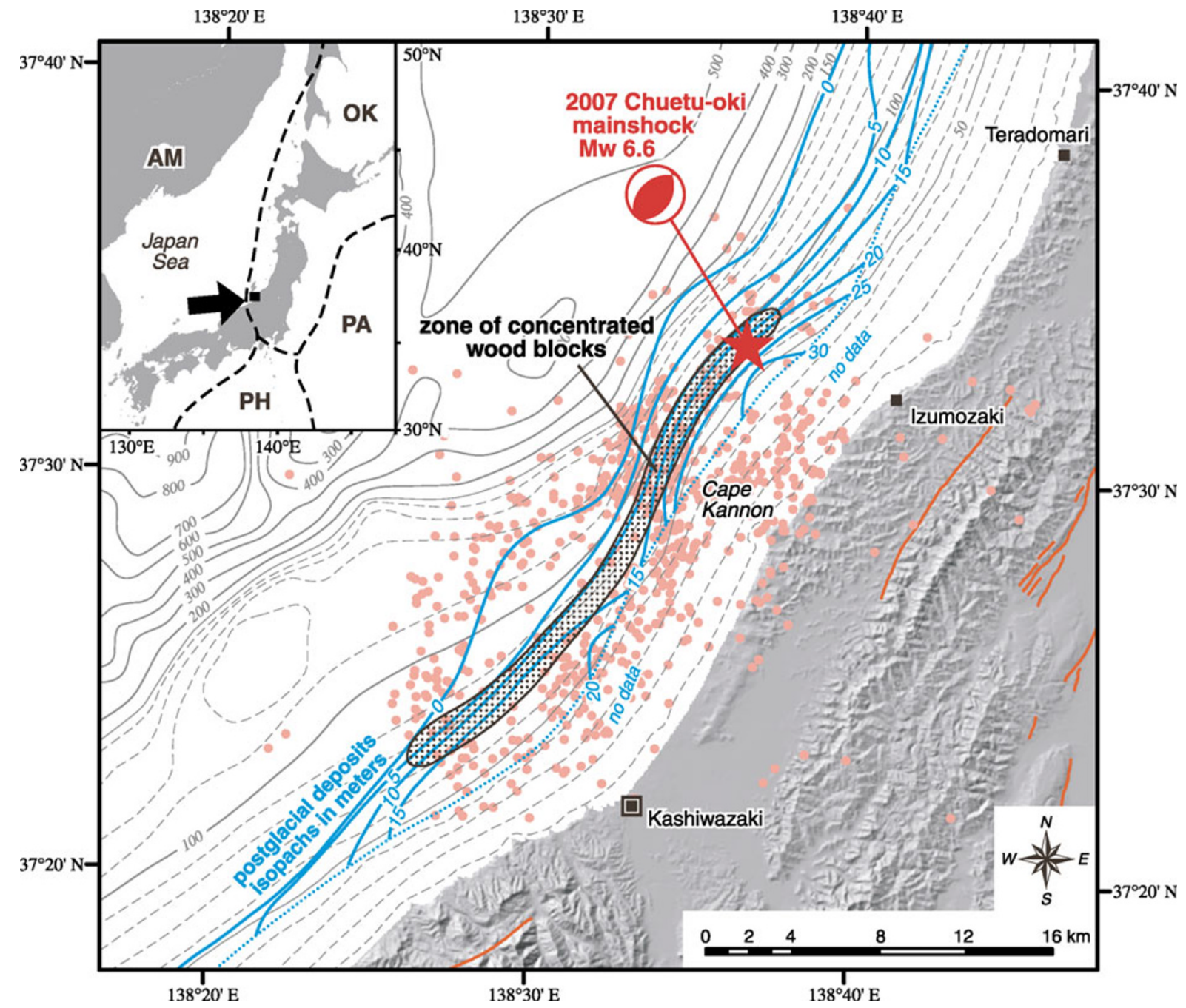

Fig. 1. Location of the zone of concentrated wood blocks that emerged during the 2007 Chuetsu-oki earthquake, based on surveys by the Niigata Prefectural Fisheries and Marine Research Institute. Locations of the mainshock and 24-h aftershocks, as determined by the Japan Meteorological Agency, are shown by a red star and pink dots, respectively. Also shown are traces of onland active faults from Nakata and Imaizumi (2002). The terrestrial topographic relief image is based on 50-m digital elevation models of the Geographical Survey Institute. Bathymetric contours (thin gray lines) are from Okamura et al. (1994). Blue contours are isopachs of postglacial deposits on the continental shelf from Katayama et al. (1994). Abbreviations in the inset: OK, Okhotsk plate; AM, Amurian plate; PA, Pacific plate; PH, Philippine Sea plate.

$3 \mathrm{~km}$ wide and approximately $25 \mathrm{~km}$ long, extending subparallel to and approximately $5 \mathrm{~km}$ off the coastline (Fig. 1). The water depth in this zone is $70-100 \mathrm{~m}$ in the northeastern part and 70-85 $\mathrm{m}$ in the southwestern part. There were no major storms and waves during the surveys nor any removal operations that could have moved the emerged wood blocks horizontally.

\section{Methods and Results}

We obtained radiocarbon ages on samples cut from eight wood blocks among the numerous wood pieces collected (Fig. 2(a)). The samples for dating were selected from pieces of typical shape and size; all dated samples are subrounded to well-rounded pieces, $20-40 \mathrm{~cm}$ long and 10$20 \mathrm{~cm}$ wide (Fig. 2(b-d)). As the exterior of the blocks showed apparent decay, we removed several millimeters of the outermost layer and sampled intact wood immediately beneath. All samples were dated by the accelerator mass spectrometry method at the Institute of Accelerator Analysis Ltd., Shirakawa, Japan. We also identified each dated wood block to genus and species by cutting out an approximately 5-mm cube and examining transverse, radial, and tangential sections under a microscope.

The dating results revealed that the wood blocks are within the range of $2500-6500 \mathrm{cal} \mathrm{yr}$ BP (Table 1). This is a time when the sea level was similar to the present level. Seven of the eight dated blocks are from deciduous broadleaved trees (CSW-A to $-\mathrm{G}$ ), and the remaining block is from an evergreen conifer $(\mathrm{CSW}-\mathrm{H})$. Six of the eight taxa live today mainly on mountain slopes or along mountain streams in a cool-temperate to warm-temperate climate. These findings, along with rounded configuration of the blocks, are clear evidence that the wood pieces do not represent in situ coastal forests of the last glacial, when the emergence zone was above sea level. Rather, the blocks were transported during the middle to late Holocene from interior mountains to a depth of approximately $100 \mathrm{~m}$ on the sea bottom and then subsequently buried by sediments until they emerged onto the seafloor in 2007. 

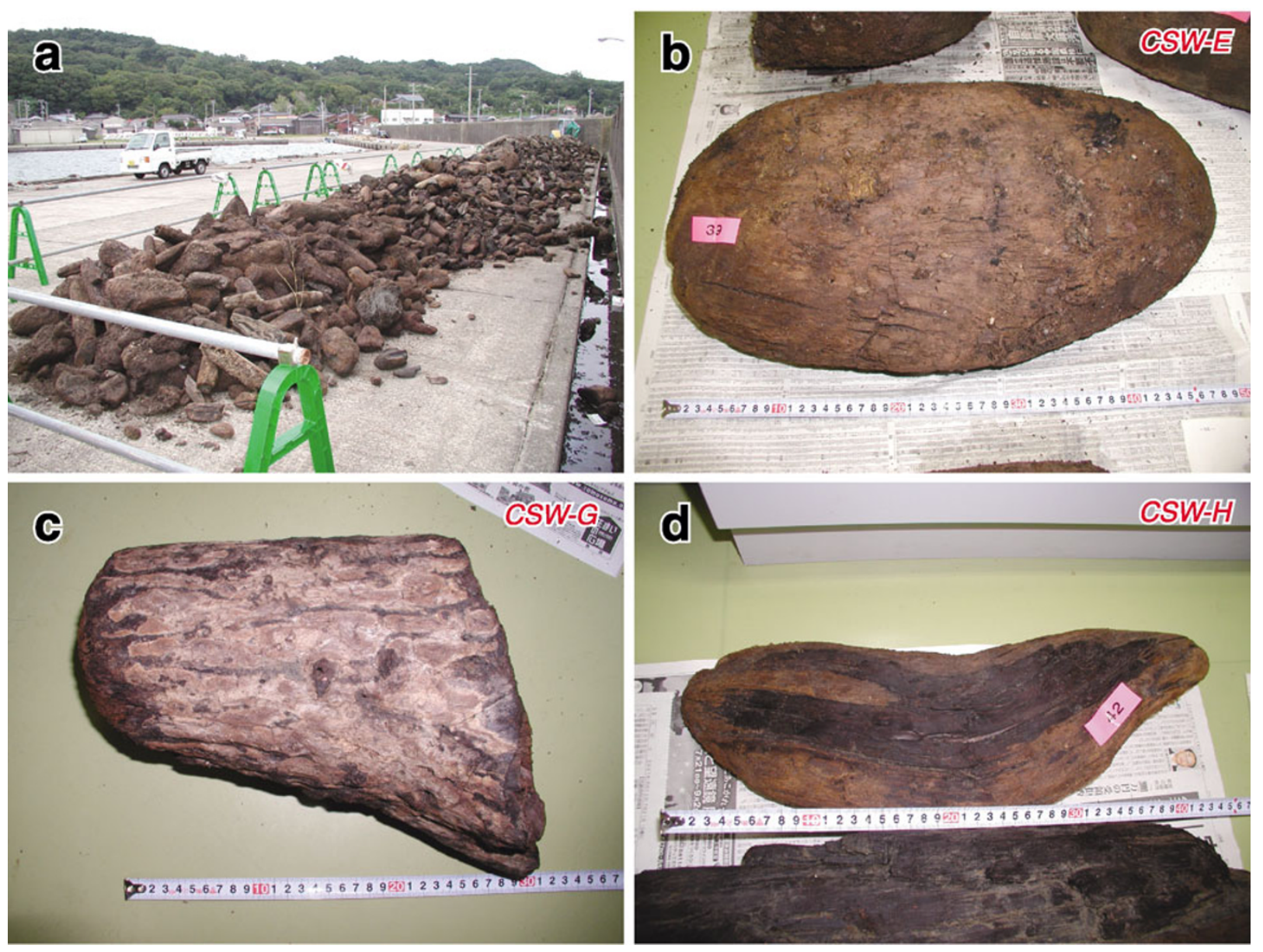

Fig. 2. (a) Wood blocks recovered in fishing nets from the seafloor off Cape Kannon. The horizontal steel bars of the barrier are approximately $1 \mathrm{~m}$ off the ground. (b-d) Examples of some of the dated wood blocks (CSW-E, -G, and -H, respectively). The tape measure is in centimeters.

Table 1. Radiocarbon ages of the wood blocks that emerged onto the seafloor during the 2007 Chuetsu-oki earthquake.

\begin{tabular}{|c|c|c|c|c|c|}
\hline Sample ID*1 & Labo ID*2 & $\delta^{13} \mathrm{C}[\% o]$ & $\begin{array}{c}\text { Conventional }{ }^{14} \mathrm{C} \text { age }{ }^{* 3} \\
( \pm 1 \sigma)\left[{ }^{14} \mathrm{C} \text { yr BP }\right]\end{array}$ & $\begin{array}{c}\text { Calibrated age*4 } \\
(95 \% \text { prob.) }[\text { cal yr BP] }\end{array}$ & Species ${ }^{* 5}$ (growth form ${ }^{* 6}$, main growing habitat ${ }^{* 7}$ ) \\
\hline CSW-A & IAAA-70650 & -23.0 & $3,230 \pm 30$ & $3,560-3,380$ & Fagus sp. (db, c-t mountains) \\
\hline CSW-B & IAAA-70651 & -25.3 & $5,550 \pm 40$ & $6,410-6,280$ & Morus australis (db, c-t to w-t mountains) \\
\hline CSW-C & IAAA-70652 & -28.0 & $2,910 \pm 40$ & $3,210-2,940$ & Pterocarya rhoifolia (db, c-t mountain streams) \\
\hline CSW-D & IAAA-70943 & -25.8 & $3,120 \pm 30$ & $3,410-3,260$ & Aesculus turbinata (db, c-t mountain streams) \\
\hline CSW-E & IAAA-70944 & -36.0 & $4,530 \pm 40$ & $5,320-5,040$ & Acer sp. (db, c-t mountains) \\
\hline CSW-F & IAAA-70945 & -28.3 & $2,950 \pm 40$ & $3,250-2,970$ & Salix sp. (db, c-t to w-t wet land and streams) \\
\hline CSW-G & IAAA-70946 & -29.1 & $4,360 \pm 40$ & $5,040-4,840$ & Alnus sp. (db, c-t to w-t wet land) \\
\hline CSW-H & IAAA-70947 & -23.2 & $2,600 \pm 30$ & $2,780-2,620$ & Cryptomeria japonica (ec, c-t to w-t mountains) \\
\hline
\end{tabular}

${ }^{* 1}$ All samples are wood, and were pretreated with acid-alkali-acid.

${ }^{* 2}$ IAAA, Institute of Accelerator Analysis Ltd., Shirakawa, Japan.

${ }^{* 3}$ All samples were dated by the accelerator mass spectrometry (AMS) method.

${ }^{* 4}$ Calibrated by using the IntCal04 data set (Reimer et al., 2004) and OxCal calibration software (Bronk Ramsey, 1995, 2001) ver. 4.0.5.

${ }^{* 5}$ Based on anatomical features of wood tissues in transverse, radial, and tangential sections. Three sections 30-50 $\mu \mathrm{m}$ thick were cut with a sliding microtome, stained with $1 \%$ safranine in 50\% ethanol, and observed under a light microscope (BX-50; Olympus, Tokyo, Japan).

${ }^{* 6} \mathrm{db}$, deciduous broadleaved; ec, evergreen coniferous.

${ }^{* 7} \mathrm{c}$-t, cool-temperate; w-t, warm-temperate.

\section{Discussion and Conclusions}

Although how the wood blocks came to be transported and deposited is enigmatic, the lack of any age younger than $2500 \mathrm{cal}$ yr BP implies that the deposition of the wood blocks had ended by approximately $2 \mathrm{ka}$. This inference is supported by inde- pendent dating results of 5000-6300 cal yr BP $(\mathrm{H}$. Sakurai, Yamagata University, personal communication) and 2200-8800 cal yr BP (Mathematical Assist Design Laboratory Inc., http://www.madlabo.com/mad/research/ 20070824_Izumozaki/index.htm\#SEC5, in Japanese) on three and five samples, respectively. 
Two mechanisms can be ascribed to the emergence of those buried wood blocks onto the seafloor: liquefaction and fluidization (Lowe, 1975). In the first case, buried wood blocks move upward by buoyancy in transitorily watersupported (liquefied) sediments because of strong ground motion. In the second case, the wood blocks are forcibly dragged by escaping (fluidized) water that is squeezed from deeper aquifers by, for instance, seismogenic faulting or folding.

We infer that liquefaction is the most likely mechanism that brought up these blocks because the submarine geology of the emergent zone is fine to very fine sand (Katayama et al., 1994), which is generally susceptible to liquefaction. In fact, an experimental study showed that the wood blocks have a wet density of approximately $1.09 \times 10^{3} \mathrm{~kg} / \mathrm{m}^{3}$, which is only slightly larger than that of sea water $(\sim 1.03$ $\times 10^{3} \mathrm{~kg} / \mathrm{m}^{3}$ ), and that they very easily float up onto the seafloor once the sediments that include the blocks liquefy (K. Izumi and Y. Nouguchi, paper presented at the Niigata University Chuetsu-oki Earthquake Symposium, October 5, 2007). In addition, the distribution of the 2007 wood blocks appears to be restricted to where the postglacial deposits on the continental shelf are relatively thin (5-20 m thick; Katayama et al., 1994; Fig. 1), which also supports the liquefaction origin of the wood block emergence because sediment compaction due to thick sedimentary cover reduces the likelihood of liquefaction of the buried wood-bearing layers.

Given the low wet density of the wood blocks tested, the buried sources of the wood blocks at depths of potential liquefaction may have been nearly emptied in 2007 . The paleoseismic implication of this inference is that the 2007 earthquake was the first earthquake during the last two millennia to have caused shaking strong enough to induce submarine liquefaction off Cape Kannon. However, we cannot rule out the possibility that multiple earthquakes are needed to void the wood sources. Wood blocks that emerged during earlier earthquakes may have been transported away or have decomposed, leaving no evidence of paleoliquefaction that occurred after approximately $2 \mathrm{ka}$. If this is the case, it is likely that there is still a larger supply of buried wood that will emerge following future large earthquakes. Further studies, such as drilling, high-resolution acoustic profiling, and more radiocarbon dating, are required to examine the paleoseismic implications of the wood-block emergence in 2007.

In conclusion, radiocarbon ages and species composition of the wood blocks that emerged onto the seafloor during the 2007 Chuetsu-oki earthquake suggest that they were transported from inland during the middle to late Holocene, buried by subsequent sedimentation, and brought up onto the seafloor in 2007, most likely by submarine liquefaction induced by strong ground shaking. Our observations may further imply the absence of large earthquakes in this area during the last two millennia, although the possibility of multiple earthquakes after approximately 2 ka cannot be ruled out if the buried wood sources cannot be emptied by a single earthquake.

Acknowledgments. We are grateful to the Department of Agriculture, Forestry, and Fisheries of Niigata Prefecture, the Niigata Prefectural Fisheries and Marine Research Institute, and the Kashiwazaki and Izumozaki Fisherman's Cooperatives for providing the collected wood blocks and information on the distribution of the wood blocks. Our gratitude also goes to H. Sakurai and F. Tokanai of Yamagata University for providing their dating results on some of the emerged wood blocks. This article was greatly improved by comments and edits of two reviewers, B. Atwater and C. Goldfinger.

\section{References}

Atwater, B. F., S. Musumi-Rokkaku, S. Kenji, Y. Tsuji, K. Ueda, and D. K. Yamaguchi, The orphan tsunami of 1700: Japanese clues to a parent earthquake in North America, U.S. Geol. Surv. Prof. Pap. 1707, 133 pp., University of Washington Press, Seattle, 2005.

Bronk Ramsey, C., Radiocarbon calibration and analysis of stratigraphy: the OxCal program, Radiocarbon, 37, 425-430, 1995.

Bronk Ramsey, C., Development of the radiocarbon program OxCal, Radiocarbon, 43, 355-363, 2001.

Geological Survey of Japan/AIST, The ground failure and the tsunami inundation by the 2003 Tokachi-Oki earthquake, Rep. Coordinating Committee Earthq. Prediction, 71, 13-17, 132-134, 2004 (in Japanese). Katayama, H., T. Nakajima, and K. Ikehara, Sedimentological map south of Sado Island, Marine geology map series 44, Geological Survey of Japan, Tsukuba, 1994 (in Japanese with English abstract).

Koseki, J., O. Matsuo, Y. Ninomiya, and T. Yoshida, Uplift of sewer manholes during the 1993 Kushiro-oki earthquake, Soils Foundations, 37(1), 109-121, 1997.

Lowe, D. R., Water escape structures in course-grained sediments, Sedimentology, 22, 157-204, 1975.

Nakata, M., Y. Hosoo, M. Tateishi, and S. Miyashita, Species composition and estimated formation process of ancient wood pieces that appeared at the sea bottom off Izumozaki after the Niigataken Chuetsu-oki earthquake in 2007, Jpn. J. Histor. Bot., 16, 19-24, 2008 (in Japanese with English abstract).

Nakata, T. and T. Imaizumi (eds.), Digital Active Fault Map of Japan, 60 pp. and 2 DVDs, Univ. Tokyo Press, Tokyo, 2002 (in Japanese).

Nanayama, F., K. Satake, R. Furukawa, K. Shimokawa, B. F. Atwater, K. Shigeno, and S. Yamaki, Unusually large earthquakes inferred from tsunami deposits along the Kuril trench, Nature, 424, 660-663, 2003.

Okamura, Y., K. Takeuchi, M. Joshima, and M. Satoh, Geological map south of Sado Island, Marine geology map series 43, Geological Survey of Japan, Tsukuba, 1994 (in Japanese with English abstract).

Reimer, P. J., M. G. L. Baillie, E. Bard, A. Bayliss, J. W. Beck, C. J. H. Bertrand, P. G. Blackwell, C. E. Buck, G. S. Burr, K. B. Cutler, P. E. Damon, R. L. Edwards, R. G. Fairbanks, M. Friedrich, T. P. Guilderson, A. G. Hogg, K. A. Hughen, B. Kromer, G. McCormac, S. Manning, C. Bronk Ramsey, R. W. Reimer, S. Remmele, J. R. Southon, M. Stuiver, S. Talamo, F. W. Taylor, J. van der Plicht, and C. E. Weyhenmeyer, IntCal04 terrestrial radiocarbon age calibration, 0-26 cal kyr BP, Radiocarbon, 46, 1029-1058, 2004.

Tone, T., Awa-shima toho-oki gyojo kuchiki chosa (Investigation of decayed wood east of Awa Island), Niigata-ken Suishi Dayori, 2, 2, 1965 (in Japanese).

H. Kaneda (e-mail: h-kaneda@aist.go.jp), M. Nakata, Y. Hosoo, Y. Sugiyama, and Y. Okamura 